positive seven-point peace-building plan for women's organisations.

Josephine Sirivi and Marilyn Havini, have long been at the forefront of this struggle. They were part of the peace process and reconciliation since their inclusion in the 1997 and 1998 negotiations in Burnham and Lincoln, New Zealand, on the future of Bougainville.

By sharing their experiences in this book, they have provided rare glimpses of the realities of Bougainville's struggle that are insightful for journalists. And they have also provided a beacon of hope and inspiration.
SEUMAS PHELAN

A former journalist on The Irish

Times who is now a senior

subeditor on The Australian

\section{Paying with her life for telling it like it is}
Veronica Guerin, starring Cate Blanchett, directed by Joel Schumacher, 2003.

$\mathrm{I}^{\mathrm{N}}$ MAGINE the outrage if Australian finance journalist Mark Westfield was shot dead for exposing the corporate crookery that went on before the collapse of insurance giant HIH. Or if the daring duo of gold Walkley winners Kate McClymont and Annie Davies were killed for reporting the Oasis rugby league affair. Or if investigative reporter Natalie O'Brien was assassinated for revealing the official lies behind the Tampa children overboard scandal.

Awful as it is, this will give you some idea of the shock and rage that convulsed Ireland over the brutal slaying of leading crime reporter Veronica Guerin, gunned down in a peaceful street outside Dublin for telling the truth about the sleazy and violent 


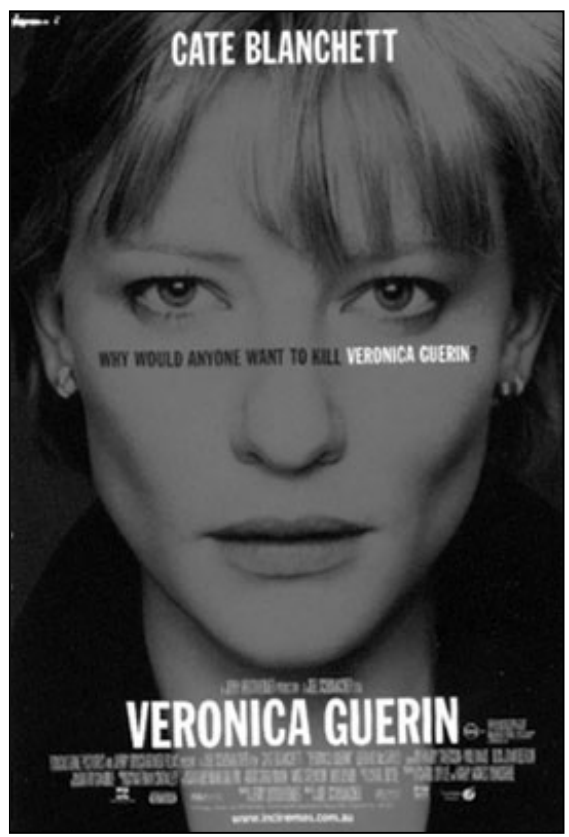

lives of the country's gangsters and drug barons.

Her story has been brought to the big screen in the film Veronica Guerin, starring Australia's Cate Blanchett in the title role. Besides being an action thriller, this movie also has major implications for anyone interested in the media and its role in exposing society's grim underbelly. Because Veronica Guerin paid with her life for doing what is any decent journalist's job - telling it like it is.

She was warned of the dangers many times. She was bashed, shot at and had her leg crippled by thugs who raided her home. Friends and colleagues pleaded with her to be more cautious, less direct. Her husband, mindful of their young son, begged her to put her family before her profession.

But Guerin was adamant. If she stopped reporting, or watered down her stories, she said, 'the bastards have won'.

Guerin worked for Ireland's biggest-selling newspaper, the Sunday Independent, part of media magnate Tony O'Reilly's empire, represented in Australia by Australian Provincial Newspapers and in New Zealand by The New Zealand Herald group. Some in the industry have criticised the company for not giving her greater protection, but the truth is she was provided with a 24-hour guard and gave it up because she found it made her work difficult.

Guerin was killed on 26 June 1996, when one of the two men on a motorcycle shot her six times as she sat in her car at traffic lights on the Naas road near Dublin. She was 37, and her son, Cathal, was six. She was murdered two days before she was due to address a conference in London titled 'Dying to Tell a Story: Journalists at Risk'.

Her killing, the first murder of a journalist in the Irish Republic, shocked the country. The then Taoiseach (prime minister), John Burton, called it an attack on democracy. The Dail (parliament) marked 
her death with a minute's silence.

In a statement, leading editors in Ireland and Britain declared: "Veronica Guerin was murdered for being a journalist. She was a brave and brilliant reporter who was gunned down for being tenacious.

This assassination led to Ireland's biggest criminal investigation, resulting in more than 150 arrests and a ruthless crackdown on the drug gangs Guerin hated - and who hated her. Crucially, it also brought about a change in the law to allow the authorities to seize the assets of criminals or others with wealth they could not account for - and this had a major impact in curbing the killer drugs that were sweeping through the Dublin slums in the 1980s and 1990s.

The film brings all this vividly to the screen. It is not strong on character development of the social and political implications of Guerin's life and work, but it is pacy and direct, and it tells a brutal story with brutal frankness.

Real life is not a Disney movie, and the truth is Guerin was a more gritty and complex character than the film portrays. She was brave and funny, but she was also drivingly ambitious, and it was always unsafe to stand between her and her career or a hot story. And she was not above stretching a yarn or using her connections with the Republic's ruling Fianna
Fail party to advance her cause.

But Guerin's death immortalised her. Long after the grubby thugs who killed her are forgotten, she will be remembered with pride and sadness not just in Ireland, but also around the globe.

Her loss has brought the dangers involved in defending the people's right to know into sharp focus everywhere. At the end of the film, the screen carries the stark message that in the years since her murder, 189 journalists have been killed all over the world - just for doing their job. phelans@theaustralian.com.au 